DOI: $10.17707 /$ AgricultForest.63.4.10

\author{
Natalia Helena JARQUIN SÁNCHEZ, \\ Erasmo VELÁZQUEZ CIGARROA, \\ José Alfredo CASTELLANOS SUÁREZ ${ }^{1}$
}

\title{
MAIN CHALLENGES OF RURAL DEVELOPMENT STRATEGIES THROUGH TOURISM AND AGRICULTURE LINKAGES IN MEXICO
}

\begin{abstract}
SUMMARY
Addressing the model of extensive rural development in Mexico, as well as based on family production units (households) strategies formulation to establish linkages between agriculture and tourism such as Pluriactivity and Propoor Tourism, necessarily implies deepening historical analysis of the governmental intervention processes. Added to this, it is crucial to refine its study based on sociological tools which will allow a more complete and comprehensive understanding of the internal dynamics of the Mexican rural family, their trade difficulties within the market and the changeling relation between the city and the countryside. Despite the efforts in the application of rural development strategies and public policies to strengthen the agricultural sector in conjunction with other economic activities such as tourism, the lack of application of participative methodologies in the elaboration of diagnoses focused on the formulation of these, constitutes one of the main causes of the failure of projects such as the insertion of Pro poor tourism initiatives or farming Pluriactivity, due to the incompatibility of these with the economic, historical, social and cultural particularities of the Mexican peasant families. It is in this sense that the present analysis is developed, thus providing relevant data for research, debate and structuring new policies aimed at improving the agricultural sector through tourism.
\end{abstract} Mexico.

Keywords: Agriculture, Household pluriactivity, Pro-poor Tourism,

\section{INTRODUCTION}

Authors such as Escalante et al. (2007), Grammont (2009) and Noreiro et al. (2009) warn that the Mexican countryside faces a decline in agriculture, which means that there is a significant decrease in the contribution of agricultural activities to income generation in rural areas, as well as to an increasing migration and aging of its population. Although this depression does not refer to the disappearance of agricultural activities, it emphasizes the importance of increased income from non-agricultural activities in rural households.

\footnotetext{
${ }^{1}$ Natalia Helena Jarquin Sánchez (corresponding author: nataliahjarquin@gmail.com), Erasmo Velázquez Cigarroa, José Alfredo Castellanos Suárez Department of Rural Sociology, Chapingo Autonomous University, Texcoco, MEXICO.

Paper presented at the 8th International Scientific Agricultural Symposium "AGROSYM 2017".

Notes: The authors declare that they have no conflicts of interest. Authorship Form signed online.
} 
This situation is due in large measure to the ravages that are experienced as a result of the intensification of the technological process under the development and modernization model that prevailed since the decade of the 1950's. In order to compete under the new commercialization trends, significant extensions of land and strong financial investments are needed. The above, entails local producers out of business which increases unemployment (Timms, 2006), in addition to establish suitable conditions for the entry of foreign products whose costs tend to be lower than those of domestic production.

Faced with these circumstances and policies that promote a greater specialization of productive units, agricultural activities face a stagnation, coupled with the phenomenon of exclusion from the domestic market, with which small and medium producers have to cope and who have gradually opted for abandoning agricultural production, even sell-squander their land, migrate (countryside-city and to the U.S mainly) and move from land owner peasant to wage-laborer. All this describes roughly the main characteristics that are part of the so-called New Rurality, an approach that, without any coincidence, goes into discussion alongside neoliberal policies and globalization circumstances such as rural pluriactivity or multifunctionality (Marsden, 1990; Grammont, 2009; Schneider, 2009; Escalante et al., 2007; Bonnal et al., 2003 Evans and Ilbery, 1993; Sacco dos Anjos, 2001), and the subsequent study of linkages between tourism and agriculture (Rogerson, 2012; Timms, 2006; Torres, 2003, 2002; Torres and Momsen, 2004) and between tourism and poor (Ashley et al., 2001; Gascón, 2011; Ventura-Dias, 2011).

The discussion presented in this paper is based on the analysis of rural development strategies aimed at agriculture strengthening through the establishment of links with one of the main economic activities of the country, tourism. Likewise, there is an urgent need to rethink methodologies such as ProPoor Tourism in Mexico, due to the multicultural and heterogeneous nature of the Mexican rural scene.

\section{MATERIAL AND METHODS}

This research starts from the concomitant complexity in the unfolding of the reconfiguration of the rural scene in front of the evident civilizational crisis that has been sharpened with the new rules that the system dictates. The spatial, social, economic, technological, environmental and cultural dimensions under which the countryside and the city interact, the design and implementation of public policies and strategies aimed at improving the delicate situation facing agriculture in Mexico, as well as global trends for rural development proposed to reduce the situation of pauperization of peasant families, represent only the tip of the iceberg that such complexity implies.

Although complexity announces the lack of simplicity, its epistemological logos compromises the integrating challenge of connections that become a whole at the time, and not a reductionist way in which the whole is analyzed separately 
in its parts, so it is necessary to start from the idea that, "complexity is a problem word and not a solution word " (Morin, 2001).

Under the previous epistemic premise, this document refers to the urgency of using participatory methodological (Selenger, 1997; Chambers, 1994), ethnographic (Guber 2011) and historical-sociological tools for the redesign of global rural development strategies such as agricultural multifunctionality or pluriactivity, synergy between agriculture and tourism, as well as Pro Poor Tourism based on family production units.

Also, an extensive documentary review of cases (national and international) was carried out in which these strategies have been implemented through public policies (Schneider, 2009; Timms, 2006; Rogerson, 2011; Torres, 2002, 2003), whose data were fundamental to the discussion and results.

\section{RESULTS AND DISCUSSION}

Since the mid-1940's, tourism in Mexico has represented an important activity of multiple opportunities and dynamism for the country's growth. According to the OECD (2017), tourism in Mexico directly represents $8.5 \%$ of GDP and generates a value above the average of the economy. However, despite the direct and indirect employment generated by tourism, there is widespread criticism of having high external leakages (Telfer and Wall, 1996), besides, important disruptive impacts above local agriculture such as land, labor, water and financial resources competition has been detected (Timms, 2006; Torres, 2003; Momsen, 1998; Telfer, 2000; Rogerson, 2012).

The potential of Mexican tourism to promote inclusive and sustainable growth has a wide margin to be exploited, suggests the OECD (2017), but the sector faces major challenges in terms of competitiveness and sustainability, among which the urgent need to promote public policies that adapt the model of tourist development to potentiate the sector in synergy with other productive sectors related to the tourism value chain.

In this regard, the Mexican government announced on December 15th, 2016, the signing of an agreement between SECTUR (Tourism Secretariat) and SAGARPA (Agriculture, cattle raising, rural development and food Secretariat) that promises to strengthen the participation of national companies as suppliers of goods and services of the tourism sector, new markets for specialty foods and local fresh produce bloom, among other potential positive impacts.

While this initiative represents an important precedent of synergy between Tourism and Agriculture, the current situation of the Mexican rural scene (significant decrease of agriculture, increasing migration, corruption, etc.), implies a challenge per se for the supply of local products to the tourism industry.

According to several researchers (Telfer, 2000; Telfer and Wall, 1996; Momsen, 1998; Torres, 2003; Timms, 2006), main challenges for agriculture and tourism linkages are related to supply or production factors such as informal nature of local farming systems; which generates mistrust on tourism enterprises about quality and quantity supply. This same issue occurs on marketing and 
intermediary related factors, where availability and quality of regional transportation, storage and distribution infrastructure fails.

Among this challenging factors, entrenched monopoly and in many cases corrupt marketing networks (Torres, 2003) is a major problem to improve agriculture and tourism linkages benefits for local producers. Despite this, Mexico has important strengths. Based on the pioneer research by Torres (2003) about agriculture and tourism linkages in Mexican Caribbean most important destination, Cancun (sun and sand tourism, characterized by Fordist mass resorts; mainly transnational chains), against all predictions about foreign owned or managed enterprises trend to depend heavily on imports, the level of foreign imports to Cancun hotels are surprisingly low, where most of fresh fruits and vegetables, dairy products, packed and bulk commodity goods are imported from different regions of Mexico thanks to the improved transportation links.

As shown, Mexico has opportunities, nevertheless, local agricultural and tourism linkages which may benefit poorer segments of population (Timms, 2006), has a discouraging future, mainly because of the lack of capital investment and technological assistance access for family farming.

\section{Family production units and Pro-Poor Tourism (PPT)}

As well as the context that emerged from the neoliberal policies, globalization and other factors, generated the need to undertake research routes in relation to pluriactivity or synergy efforts between agriculture and tourism; there was also a concern to analyze the links between tourism and poverty. Hence, the evaluation of how tourism has been able or could contribute to the reduction of poverty through "Pro-Poor Tourism” (Ashley et al., 2001; Torres and Momsen, 2004).

However, Pro-Poor Tourism Methodology may not be the way to achieve poverty relief in Latin America due to evidence of ambiguity regarding the concept of "poverty" that may not fit with Mexico's or other Latin American impoverishment conditions. Added to this, several researchers such as VenturaDias (2011) and Ashley et al. (2001) warn that there is no empirical evidence that tourism has succeeded in becoming a positive instrument in the eradication of poverty.

About this, Gascón (2011) states that the PPT methodology discloses contradictions in relation to paradigms such as Food Sovereignty when resorting to transnational tourism capital as an investment partner, a situation that suits the reproduction of the neoliberal economic model, which largely represents the origin of the exclusion, marginalization and impoverishment of peasant families and indigenous communities in countries such as Mexico.

In consideration that Mexico's most representative touristic destinations have a high symbolic load of folklore that inevitably evokes either the preHispanic past or the richness of the cultural diversity of rural Mexico, as well as being located in beautiful natural landscapes, it is not strange that these tourist destinations are located near rural locations. In this sense, Mexican farm household is the main cultural and social structure in rural spaces, that is to say, 
countryside families are the most vulnerable people to whom tourism affects, as well as the sector to which agriculture-tourism linkages policies should consider.

For this purpose, it is necessary to recognize the potential of peasant families in the current capitalist economy towards the creation of tourism and agriculture linkages for a better future scenario to poor Mexican peasant families, to deepen the analysis of the internal dynamics of the Mexican rural family and how these interact with the current market mechanisms. There is also a profound need to lead understanding about capital accumulation and its propagation process, the prominence of the State, the increasing complexity and power of the non-agricultural parts of the food chain, as well as to seek conceptual flexibility about assumptions often implied in the analysis of agricultural development (Marsden, 1990).

Therefore, the study of family production units in pluriactivity framework (alternation of agricultural activities and tourism) offers a more adequate way of analyze structural processes in Mexico, a fundamental understanding for the subsequent development of public policies and strategies aimed at halting the decline of conditions of agriculture in the Mexican rural sector, and consequently the living conditions of its marginalized population.

This marginalization and exclusion is exposed by several researchers (Marsden, 1990; Aguilar et al., 2010; Timms, 2006), who highlight evidence regarding the difficulty faced by most rural families in obtaining loans for entrepreneurship or improvement of productive projects because multiple credit agencies set very particular conditions on loans and are selective about which types of farmers receive them. This problem extends even with loan plans granted by the State, and the inflexibility of its operation rules. More worrying the high degree of productive projects that finally fail because of the lack of technical follow-up and the high level of dependence that this type of federal programs generates through one of the main problems of Mexican rural development policies: paternalism.

On the other hand and based on the challenges previously described for rural families, such as the difficulty of competing with specialized agro-industrial companies for lack of access to capital investment, technology and technical assistance, there is a lack of accounting and administrative training, fundamental to any entrepreneurial success.

In order to overcome this type of challenges, and taking into account the potential of family agricultural production units and the development of tourism as a complementary activity, it is important that the incipient policies for synergy between these sectors of the economy in Mexico consider specialized strategies in the promotion of markets directed to the consumption of community tourism, whose projection should be focused on the multifunctional and integral exercise of the agricultural and tourist activity as well as autonomy and self-management of their resources.

Although the creation of cooperatives and the operation of principles of solidarity economy are attractive to form united fronts of local producers to cover 
the demand in quantity and quality of accommodation establishments as well as food and beverages, strategies must be anticipated to maintain the unity of these cooperatives and avoid situations of abuse, theft and corruption; unfortunate problems concomitant to the fragile economic situation and the paternalistic Welfare State especially for the rural and peasant sphere.

\section{CONCLUSIONS}

It is necessary to consider the particularities of the Latin American and Mexican context in order to overcome challenges that pluriactivity and agriculture and tourism linkages have. Otherwise, exogenous models of economic development based on the diversification of the agricultural and rural sector, may be incompatible.

There is a need for the formulation of economic policy proposals that encourage the integration of rural families into pluriactivity; however, it is necessary not to advance high expectations in this regard, without first elaborating strategies aimed at strengthening traditional forms of production.

It is also urgent to incorporate participatory methodological tools designed for the rural sector in the elaboration of diagnoses for the formulation of productive projects that, through links between agriculture and tourism, strengthen the Mexican countryside and thereby improve the quality of life of the Rural family. That is, to recognize the value of the information that arises from the families themselves: "locals know better".

According to self-experience in projects linking agriculture and tourism in two rural communities on the coast of the State of Oaxaca in Mexico, a careful diagnosis that details economic, environmental, social and cultural aspects is required. Such a diagnosis must consider cultural diversity and otherness as determinant factors, since it opens up opportunities for innovative entrepreneurship, products specialization and new niches opening. The recognition of local families as the main data source and main driver for economic and productive activation is crucial to strengthen the project within the community, otherwise the risk of failure increases greatly. Therefore, the ethnographic work and the application of a participatory rural diagnosis, represent the channels of interlocution between the community, social and economic theory.

In this sense, the undertaking of productive projects of a tourist and agronomic nature through cooperatives or solidarity societies in Protected Natural Areas and/or Native reserves in Mexico, often fail because of the lack of legal commitments by the project members, absence of a realistic business plan, lack of accounting, administrative and technical-operational training (CONANP, 2014).

\section{REFERENCES}

Aguilar J/ Reyes J and Rendón R. (2010). Del extensionismo agrícola a las redes de innovación rural. (From agricultural extension to rural innovation networks). $1^{\text {a }}$ ed. Universidad Autónoma Chapingo. CIESTAAM. México. 
Ashley C/Roe D and Goodwin H. (2001). Pro-poor tourism strategies: Making tourism work for the poor. Pro-poor tourism Report no. 1. London: Overseas Development Institute, International Institute for Environment and Development, and Centre for Responsible Tourism, University of Greenwich. $1-54$.

Bonnal P./Bosc P.M./Diaz J and Losch B. (2003). Multifuncionalidad de la aricultura y Nueva Ruralidad. ¿Reestructuración de las políticas públicas a la hora de la globalización? (Multifunctionality of ariculture and New Rurality. Restructuring of public policies at the time of globalization?) Ponencia presentada en el Seminario Internacional El Mundo Rural: Transformaciones y Perspetivas a la luz de la Nueva Ruralidad. Universidad Javeriana, CLACSO, REDCAPA, 15-17 de octubre de 2003. Pp. 1-23 Bogotá, Colombia.

Chambers R. (1994). The Origins and Practice of Participatory Rural Appraisal. World Development 22(7), pp. 953-969.

CONANP (2014). Estrategia Nacional: Negocios Sociales Sustentables 2014-2018. (National Strategy: Sustainable Social Business 2014-2018). Oficina del Comisionado Nacional. México. http://www.conanp.gob.mx/pdf_publicaciones/TurismoEstrategia.pdf Accessed on 16/03/17

Escalante R/Catalán H/ Galindo L. and Reyes, O. (2007). Desagrarización en México: tendencias actuales y retos hacia el futuro. (Disagrarization in Mexico: current trends and challenges for the future). Cuadernos de Desarrollo Rural, Julio- Diciembre, Núm. 59. pp. 87-116.

Evans N. \& Ilbery B. (1993). The pluriactivity, part-time farming, and diversification debate. Environment and Planning 25(7), pp.945-959.

Gascón J. (2011). La metodología Pro Poor Tourism: un análisis crítico. (The methodology Pro Poor Tourism: a critical analysis). Opiniones en Desarrollo. Programa Turismo responsable. Alba Sud Investigación y comunicación para el desarrollo. Enero No. 9. Accessed on 9/02/17

Grammont H. (2009). La desagrarización del campo mexicano. (The dezagralization of the Mexican countryside). Convergencia. Revista de Ciencias Sociales 50(16), pp.13-55.

Guber R. (2011). La etnografía: Método, campo y reflexividad. (Ethnography: Method, field and reflexivity). Primera edición Siglo XXI Editores. Buenos Aires.

Marsden T. (1990). Towards the Political Economy of Pluriactivity. Journal of Rural Studies 6(4), pp. 375-382.

Momsen J. (1998). Caribbean Tourism and Agriculture: New Linkages in the Global Era? In: The Caribbean Context, Globalization and Neoliberalism. Klak Lanham. Rowman and Littleman Publishers Oxford. pp. 115-133.

Morin E. (2001). Introducción al pensamiento complejo. (Introduction to complex thinking). Editorial Gedisa. Quinta reimpresión, Barcelona.

Noreiro L/ Torres G/ Almanza M. and Ramírez C. (2009). Nueva ruralidad: enfoques y sinergias. Emergencia de un modelo alternativo de desarrollo. (New rurality: approaches and synergies. Emergence of an alternative model of development). Textual. Análisis del medio rural latinoamericano. Universidad Autónoma Chapingo. No. 53, pp. 77-102. 
OECD. (2017). Estudios de la Política Turística de México. (Studies of the Tourist Policy of Mexico). Ed. en español: Secretaría de Turismo de México. https://www.oecd.org/centrodemexico/medios/Estudios\%20de\%20la\%20Pol\% C3\%ADtica\%20Tur\%C3\%ADstica\%20de\%20M\%C3\%A9xico_CUADERNI LLO.pdf Accessed on 12/04/2017

Otero G. (2004). ¿Adiós al campesinado? Democracia y formación política de las clases en el México rural. (Farewell to the peasantry? Democracy and political class formation in rural Mexico). Primera edición. Universidad Autónoma de Zacatecas, Simón Fraser University, México.

Rogerson C. (2012). Strengthening agriculture-tourism linkages in the developing world: Opportunities, barriers and current initiatives. African Journal of Agricultural Research 7(4), pp. 616-623.

Sacco dos Anjos F. (2001). Agricultura familiar, pluriactividad y desarrollo rural en el sur de Brasil. (Family farming, pluriactivity and rural development in southern Brazil). Revista Internacional de Sociología, Enero-Abril (28), pp. 173-205.

Schneider S. (2009). La pluriactividad en el medio rural brasileño: características y perspectivas para la investigación. (Pluriactivity in the Brazilian rural environment: characteristics and perspectives for research). pp. 207-242. In: Grammont, H. \& Martínez, L. [eds]. La pluriactividad en el campo latinoamericano. Ed. Foro de FLACSO. Quito, Ecuador.

Selenger D. (1997). Participatory action research \& social change. New York: Cornell University.

Telfe D. (2000). Tastes of Niagara: Building strategic alliances between tourism and agriculture. International Journal of Hospitality and Tourism Administration 1(1), pp. 71-88.

Telfer D. \& Wall G. (1996). Linkages between tourism and food production. Annals of Tourism Research 23(3), pp. 635-653.

Timms B. (2006). Caribbean agriculture-tourism linkages in a neoliberal world. Problems and prospects for St. Lucia. International Development Planning Review, 28(1), pp. 35-56.

Torres R. (2002). Towards a better understanding of Tourism and agriculture linkages in the Yucatan: tourist food consumption and preferences. Tourism Geographies 4(3), pp. 282-366.

Torres R. (2003). Linkages between tourism and agriculture in Mexico. Annals of Tourism Research 30(3), pp. 546-566.

Torres R. \& Momsen J.H. (2004). Challenges and potential for linking tourism and agriculture to achieve Pro-Poor Tourism objectives. Progress in Development Studies, 4(4), pp. 294-318.

Ventura-Dias V. (2011). El turismo, su cadena productiva y el desarrollo incluyente en America Latina: los casos de Brasil y México. (Tourism, its productive chain and inclusive development in Latin America: the cases of Brazil and Mexico). Serie Comercio y Crecimiento Incluyente. Working Paper No. 138. Red Latinoamericana de Política Comercial (RedLATIN), septiembre 2011, Buenos Aires. 